\title{
The agrarian historiography of Chile: Foundational interpretations, conventional reiterations, and critical revisionism
}

\author{
Claudio Robles
}

KEYWORDS: Chile, agrarian historiography, rural history, hacienda system.

JEL CODES: N01, N56, K11, B30.

his article examines the development of Chilean agrarian historiography in
the last four decades, by means of an introductory overview organized as a
chronological reconstruction. It selectively focuses on relevant authors and works, the problems and questions they addressed, their main arguments and contributions, as well as their flaws and limitations. In doing so, the article constructs debates that never took place, because development of this field has been limited by the scarcity of specialized works, the different contexts in which they were produced, and the lack of institutional spaces for systematic debate. Agrarian historiography has only recently become a distinctive discipline in Chile and is therefore an incipient field. In the last fifteen years, a new revisionist agrarian historiography has begun to revitalize the study of Chilean rural history through critical dialogue with foundational interpretations from the 1970s, leaving behind the conventional reiterations of the 1980s. 


\section{La historiografía agraria de Chile: Interpretaciones fundacionales, reiteraciones convencionales y revisionismo crítico}

\section{PALABRAS CLAVE: Chile, historiografía agraria, historia rural, sis- tema de hacienda.}

\section{CÓDIGOS JEL: N01, N56, K11, B30.}

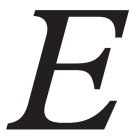

ste artículo examina el desarrollo de la historiografía agraria chilena en las últimas cuatro décadas, por medio de una revisión introductoria y organizada como una reconstrucción cronológica. Esta se enfoca selectivamente en autores y trabajos relevantes, los problemas y preguntas que tratan, los principales argumentos y contribuciones que ofrecen, así como sus limitaciones y debilidades. Este ejercicio construye debates que nunca tuvieron lugar, ya que hasta hace poco tiempo el desarrollo de esta disciplina fue limitado por el escaso número de trabajos especializados, los diferentes contextos en que fueron producidos y la falta de espacios institucionales para el debate disciplinario sistemático. En tanto disciplina especializada, la historiografía agraria se ha constituido recientemente en Chile; así, es todavía un campo de trabajo incipientemente cultivado. En efecto, sólo en los últimos quince años una nueva historiografía agraria revisionista comenzó a revitalizar el estudio de la historia rural chilena, por medio de un diálogo crítico con las interpretaciones fundacionales de la década de 1970, dejando atrás las reiteraciones convencionales de los ochenta.

Received: 2019-06-02 - Revised: 2019-11-06 - Accepted: 2019-11-13

Claudio Robles [orcid.org/0000-0003-3041-7838] is Associate Professor of Economic History at the Universidad de Santiago de Chile (USACh), and Director of the Centro de Estudios de Historia Agraria de América Latina (CEHAL). Address: Department of Economics, Av. Bernardo O'Higgins 3363, Santiago (Chile).E-mail: claudio.robles@usach.cl 


\section{INTRODUCTION}

This article analyzes the trajectory of the agrarian historiography of Chile, broadly understood, from the 1970s to the present. Focusing selectively on relevant works, it discusses the problems and questions that these previous studies examined, the main arguments and contributions they proposed, and critically reflects on their flaws and limitations. This exercise implies constructing debates that, for the most part, never took place because of the small number of works in the field, the different contexts in which they were produced, and, especially, the lack of systematic disciplinary debate. Thus, this article is an effort to provide an organized account of what has been until recently a rather fragmented scholarship. Despite any arbitrariness it surely involves, this critical account seeks to contribute to the transformation of Chilean agrarian historiography into a coherent disciplinary field.

Chilean rural, agrarian, and agricultural history have been dealt with in works of different nature and quality, produced in several disciplinary areas. However, these works have also dealt with similar issues, which have been the themes of a rather peculiar agrarian historiography. General economic history concentrated on agriculture's role in the development of the Chilean economy, especially in the era of export-led growth based in the nitrate industry (1880-1930) and the so-called agricultural stagnation after the Great Depression. For other scholars, in turn, the central problem was whether rural society, especially that of Central Chile, remained traditional or backward, or if agriculture underwent any degree of modernization, and took part in the transition towards capitalism that the economy underwent from the middle of the nineteenth century. General social history, rural sociology, and human geography studies shared an interest in the agrarian structure, the persistence of the large rural estate and its role as latifundium, while, at the same time, discussing inquilinaje as a "pre-capitalist" labor system. More recently, the agrarian reform (1967-73) is another example of a subject addressed by scholarship in different disciplines, such as economics and agrarian political economy ${ }^{1}$.

Therefore, it can be argued, agrarian historiography has just recently formed in Chile as a distinctive discipline. Thus, it is still an under-cultivated field of scholarship. There are insufficient research and publications, both books and journal articles. As a result, agrarian historiographic debates are incipient, at best. The exception is the work by scholars who have carried out their research being informed by and in dialogue with scholarship produced in international academic communities. Further, agrarian historiography

1. The Chilean agrarian reform was implemented from 1967 to 1973, and then, after the 1973 coup d'état, unraveled by the military dictatorship; a valuable, yet underrated, introduction in Huerta (1989). 
in Chile is under-represented in the university curriculum and is just beginning to gain its own institutional place, such as regularly-held conferences and specialist journals. In sum, there is much ground to cultivate.

To make sense of past, recent, and current scholarship on Chilean rural society, the following five sections of this article proceed as follows. The next section discusses the foundational interpretations that established agrarian history as a scholarly discipline in the 1970s, namely, the contributions made by Arnold Bauer and Cristóbal Kay. Then, the article deals with the conventional reiterations in the works by Chilean scholars in the 1980s and 1990s, which, basically, restated or oversimplified arguments proposed in the foundational historiography. The following section discusses what can be called revisionist agrarian historiography, comprised of works produced in the past decade and a half and in critical dialogue with Bauer and Kay's interpretations. Next, the article examines current and research by Chilean and foreign scholars. Finally, the last section offers suggestions for future research.

\section{FOUNDATIONAL INTERPRETATIONS}

The study of agrarian history gained traction in the 1960s when rural society and the agricultural sector were at the center of the intense political conflict that was rapidly polarizing Chilean society. At the same time, academic interest in agrarian history was a reflection of the imminent agrarian reform that the progressive social and political forces of Chilean democracy were just about to carry out, and which soon would drastically transform the countryside. In that context, growing attention to the "agrarian problem", stimulated research not only in the social sciences but also in academic historiography. That was the case of what we can consider being the "foundational interpretations" of Chilean agrarian historiography, which Arnold J. Bauer and Cristóbal Kay proposed more than four decades ago, from economic history and agrarian political economy, respectively. These scholars' main works were virtually contemporary and informed by the same pressing agrarian issues Chile faced in the 1960s; yet, they featured quite different theoretical and methodological approaches, and thus also offered contrasting interpretations of the course of Chilean rural society.

Arnold J. Bauer, who grew up working at his family's farm in Kansas (Bauer, 2012), began his intellectual journey as a historian of Latin America by writing a doctoral dissertation at UC Berkeley in 1969, under the unpretentious title "Chilean Rural Society in the Nineteenth Century". This pioneering study on the export-led phase of Central Chile's estate agriculture (c. 1850-1890) became Chilean Rural Society from the Span- 
ish Conquest to 1930, an engaging monograph published in 1975 in Cambridge's prestigious Latin American Studies series that remains to this day the best book on Chilean rural history ${ }^{2}$. Bauer not only expanded his thesis into a more comprehensive interpretation of the oligarchic rural economy and society gone with the Great Depression but also developed a reflection on the long-term trajectory of rural Chile, by then experiencing the repressive, military aftermath of the agrarian reform.

Bauer emphasized that "traditional" Chilean rural society did not experience substantive transformations before 1930, while other cereal-producing agrarian systems modernized, or newly constituted capitalist agriculture emerged on frontier societies under the stimulus of the Atlantic market (Bauer, 1975) ${ }^{3}$. As land was abundant and labor cheap, landowners expanded production by bringing more land under the plow, and extending the labor tenant system known as inquilinaje, but in a harsher form, with fewer benefits and more labor obligations (Bauer, 1971, 1975). Thus, unlike their Russian or American counterparts, who ended serfdom and slavery, respectively, in the second half of the nineteenth century, large landowners did not abolish rural Chile's "peculiar institution". In addition, they hired more waged laborers as seasonal peons, especially for the labor-demanding harvest season. Agricultural modernization was limited to the construction of irrigation channels and late and superficial introduction of machinery. Following the ground-breaking work by Chilean geographer Silvia Hernández (1966), Bauer held that mechanization, a distinctive element of agricultural modernization, took place only within a minority of properties, which indeed became "model estates" but were not representative of the rural landscape at large.

Interestingly, Bauer also explained the absence of modernization in agriculture by looking at Chile's broader social and political context. Until the late nineteenth century, large estates were micro-societies where power was exerted and contested in the framework of paternalism and deference. At the same time, after the 1874 electoral reform, which enfranchised them, rural workers constituted a source of votes that allowed landowners to retain a great deal of influence in the State. In sum, landowners had compelling reasons not to transform rural society; thus, the insertion of Chilean agriculture into the Atlantic market reinforced traditional rural society ${ }^{4}$.

2. Indeed, albeit belatedly, this book merited the, at the time, rare privilege of a Spanish-language edition in Chile; see Bauer (1994).

3. Bauer would not conceptually elaborate on what he exactly meant by traditional but, unlike contemporary Marxist Chilean scholars, he avoided such vague notions as semi-feudal or neo-feudal to characterize nineteenth-century rural society.

4. An important work on internal migrations that is relevant to an understanding of the agrarian expansion, was Johnson (1978), a doctoral dissertation supervised by Bauer. 
Chilean Rural Society's merits notwithstanding, Bauer did not study several topics or discussed them with limited empirical data, which called into question important elements of his interpretation. First, he dealt only with Central Chile, leaving aside other regions and rural societies, whose formation, trajectory, and agrarian structures were different, as La Frontera or Llanquihue. Further, Bauer did not examine the economic performance of the agricultural sector before 1930. In fact, given the poor quality of the Chilean official statistical sources, his main interest [was] not a futile quest for numerical accuracy but rather the effect that an undoubted expansion had on the agrarian structure and rural society (Bauer, 1975: 123). Moreover, assuming that statistical sources were not suitable to estimate machinery imports or stocks, Bauer did not establish the trends in mechanization. Although his book includes valuable information from account books of three large haciendas, it did not offer an analysis of the dynamics of the units of production, either haciendas or lesser rural estates. This is especially relevant regarding Bauer's argument about the extension of inquilinaje, which is based only on the case ofViluco, a wealthy hacienda in the Maipo Valley, just south of Santiago, according to a report published in 1872 in the Boletin de la Sociedad Nacional de Agricultura (BSNA). Most significantly, Chilean Rural Society did not offer a systematic study of rural conflicts; yet, Bauer argued that the absence of social conflict was a distinctive aspect of Chilean rural society until late in the twentieth century. In particular, he regarded rural workers' first expressions of collective action in the early twentieth century, discussed in Brian Loveman's (1976) groundbreaking study of rural politics, as circumstantial. Thus, Bauer pointed out that, unlike Revolutionary Mexico, there were not massive rural revolts in Chile ${ }^{5}$.

Working almost contemporaneously with Arnold Bauer, Chilean economist Cristóbal Kay, then a member of the Centro de Estudios Socioeconómicos (CESO) at the Universidad de Chile, produced what might be considered the heterodox foundational interpretation of Chilean agrarian history. In his "Comparative Development of the European Manorial System and the Latin American Hacienda System: An Approach to a Theory of Agrarian Change for Chile", a doctoral dissertation in Development Studies, completed at Sussex in 1971, Kay advanced a theory of change to agrarian capitalism in Chile, although not focusing on agriculture as an economic sector, or on rural society, but on the long-term evolution of the hacienda system, conceptual approach that he constructed to examine the Chilean variant of the Latin American large estate (Kay, 1971, 1980). This was, in fact, not only a pioneering effort in agrarian political economy but also

5. Since Brian Loveman's book was published in 1976, Bauer discussed the former's arguments on rural conflict as presented in his doctoral dissertation; see Loveman (1973). In addition, important contributions on rural conflict produced shortly after the publication of Bauer's book included the works by Carrière (1977), and Stickell (1979). 
an exceptional work, because of its theoretical complexity and explicitly comparative perspective.

Drawing on Chilean geographer Rafael Baraona's (1965) multi-enterprise approach to the Latin American hacienda Kay conceptualized the large estate as a hacienda system, that is, a complex of conflicting economic and social relationships between peasants and landlords (Kay, 1979: 24). Thus, the hacienda system comprised the "landowner enterprise" (or demesne, if we employ the European conceptualization), the external peasant enterprises of smallholders (typically called minifundistas), and the internal peasant enterprises represented by inquilinos or tenant laborers. The vast majority of these permanent resident workers were campesinos, in the most precarious sense, as the landowners gave them small land allotments (raciones de tierras) within the estate as part of their perquisites (called regalias), earning a daily wage (jornal), in addition. Frequently, the inquilinos were also sharecroppers; thus, and the relationship known as mediería (sharecropping) also played a role in the functioning of the hacienda system.

Furthermore, Kay placed the Chilean case in a broader comparison between the Latin American hacienda system and the East European manorial system, especially that of Eastern Europe, which he approached through the conceptualization developed by the German liberal agrarian historiography (Hagen, 1998). From that perspective, in the second half of the nineteenth century, the Chilean hacienda system transitioned from a peasantdominated grundherrschaft to a landowner-dominated gutsherrschaft. Landowners, Kay argued, expanded direct cultivation on the landowner enterprise, which increased the demand for labor and land value. In response, they augmented inquilinos' labor obligations and reduced their land allotments and perquisites, and, in partial compensation, introduced a wage paid in money. At the same time, instead of settling more inquilinos, Chilean hacendados hired more peons, who engrossed the ranks of waged laborers. Thus, the $h a-$ cienda began to depend on the external supply of wage labour, and reduced the relative importance of tenant labour supplied by the inquilinaje system. Those changes, combined with technological improvements, set in motion the dissolution process of the hacienda system, as reflected in the proletarianization of its labor force, especially after 1930 (Kay, 1971: 120-21). Kay's criticism of Bauer's narrow conceptualization of proletarianization was of particular relevance. This process, Kay (1977) noted, included the experiences of peasants who could no longer find access to land and had to migrate permanently to other regions and take up other activities. It also comprised the increasing integration as temporary hacienda system laborers of many others who, not being able to support themselves from their fragmented smallholdings, became a rural proletariat that inhabited towns and rural villages. Finally, proletarianization also affected inquilinos, whose land and pasture benefits were reduced, and their ability as producers was thereby curtailed, so that their in- 
come derived from wages as opposed to production fringe benefits became increasingly important (Kay, 1977: 65). In sum, the hacienda system began transitioning to agrarian capitalism through a Junker road.

Interestingly, Kay's heterodox foundational interpretation of agrarian expansion was consistent with other scholars' characterization of Chilean agriculture, as being capitalistic from the beginning of the twentieth century. This view implied rejecting as erroneous the mainstream view among left-wing intellectuals, for whom it was either traditional, noncapitalistic or even semi-feudal, as historians affiliated with the Communist Party suggested. From the "new left," in contrast, the determination of the character of the agricultural sector was quite different. As human geographer Silvia Hernández (1972) argued, capitalist development in the countryside was taking place since 1930. Similarly, economists Sergio Aranda and Alberto Martínez (1970: 118) characterized the agricultural sector as capitalistic because wage labor was the dominant social relationship, but stressed that it was a weak capitalism, limited by the non-agrarian interests of the monopolistic bourgeoisie. Yet, unlike Bauer's interpretation, which became the conventional wisdom, at least in Chile Kay's contribution remained unfortunately a rather unknown alternative view. This was the case even though a Spanish-language abridged version of Kay's dissertation was published in Chile by Grupo de Estudios Agro-regionales (Kay, 1986).

In sum, Arnold Bauer and Cristóbal Kay offered quite different treatments and contradicting interpretations about the character of the agrarian expansion that took place in Chile during the export-led economy period, c. 1850-1930. This was especially the case regarding the degree of transformation of the large estate and rural labor systems, which led these authors to reach opposite conclusions on broader themes, such as the development of agrarian capitalism. Likewise, Bauer and Kay produced contrasting "grand reflections" on the long-term trajectory of Chilean rural society. For Bauer, it remained a traditional society well into the twentieth century, until the agrarian reform (1967-1973), and the counter-agrarian reform imposed by the military dictatorship (1973-1990) that instituted agrarian capitalism. Kay, in contrast, argued that the transition towards agrarian capitalism was developing before 1930 and it was almost completed when the state implemented an agrarian reform aimed at improving the efficiency of the agricultural sector. From the standpoint of agrarian historiography, however, the foundational interpretations shared some essential elements. In both cases, the authors dealt with Central Chile, certainly the agricultural core of colonial origins, but just one of the several distinct agrarian regions and societies that developed and still exist in Chile. Along with a limited geographic scale, their treatments of agrarian history were chronologically restricted. Bauer empirically dealt only with the 1850-90 phase of export-growth, while Kay did not carry out detailed empirical treatment of agrarian development before 1930, as his organizing 
focus was the agrarian reform. Furthermore, neither Bauer nor Kay worked with primary sources directly produced by the large estates, the unavailability of which, is to date, an important limitation in Chilean agrarian historiography.

\section{CONVENTIONAL REITERATIONS}

Following the 1973 coup d'état, the military dictatorship shut down research centers and university institutes, persecuted many researchers or forced them into exile, and destroyed a wealth of documentation related to the agrarian reform. As a result, most of the relevant scholarship on agrarian topics came to be done by researchers working outside Chile, especially in the form of doctoral dissertations at European and American universities, and articles in international disciplinary journals, to which Chilean scholars had limited, if any, access. The exceptions to this decline were the invaluable efforts made by Chilean scholars working at several NGOs, the new institutional environment that, at least partially, compensated for the marginalization of agrarian studies at the university level.

At the same time, in Chile, agrarian historiography was prevented from developing into a robust academic discipline, which was reflected in the scant number of new works and the absence of historiographic debate. Indeed, the few works by Chilean authors dealing with agrarian history published in the 1980 s can be regarded as conventional reiterations, since they did not make substantial contributions to what the foundational interpretations of the previous decade had offered. More specifically, these works restated or presented over-simplifications of arguments proposed by either Bauer or Kay. This limitation resulted from the fact that they were not based on substantial archival research and, therefore, contributed little significant new empirical evidence to what had been produced in previous works. In addition, the authors of "conventional reiterations" focused on the same period and topics, namely, Central Chile's hacienda and its labor systems in the second half of the nineteenth century. This article will briefly discuss the conventional reiterations according to the dates they were published. In evident consonance with Cristóbal Kay's interpretation, Chilean human geographer Roberto Santana (1980) argued in his Paysans dominés that the development of Chilean agriculture could be understood as the modernization process of a dependent agrarian capitalism. Further, his discussion of nineteenth-century agriculture reiterated Kay's point regarding the inquilinaje system as, Santana writes, a case of rural proletarianization, for, in his view, this labor regime underwent a process of gradual differentiation since 1930 (Santana, 1977, 1980). Nevertheless, without presenting any supporting evidence, Santana went on to add that the proletarianization of inquilinaje took place in the second half of the nineteenth century. Thus, Santana's version is a reiteration of Kay's, even though there is no reference to the latter's work. That 
is also the case in the Spanish-language, extended edition of Paysans dominés, published in Chile in 2006.

The hacienda system in the phase of agricultural export growth (c. 1850-90) was also discussed by historian Gabriel Salazar (1984) in some chapters of his general economic history doctoral dissertation on Chile's transition to industrial capitalism (c. 1820-78, according to the author); partially published later as a social history of the rural popular classes (Salazar, 1985). Departing from Bauer, Salazar discussed mechanization, interpreting it as part of a significant economic transformation [...] in the agricultural enterprises, which had a clear capitalist content (Salazar, 1984: 234). As Kay previously suggested, Salazar underscored a transition to agrarian capitalism. However, this was for only a minority of agricultural enterprises, restating Bauer's idea of modernization being restricted to "model estates". Similarly, Salazar attributed mechanization and agrarian capitalism among large estates to capital investment by the "merchant-bankers". This point was already made by Bauer, who stressed that for wealthy merchants and miners, buying a large estate was both a secure investment and a way to climb into the ranks of the landed oligarchy. As for transformations in rural labor systems, the author leaned towards Kay's view, making a case for the semi-proletarianisation of inquilinaje. Salazar (1985: 165-66) argued, with no evidence, that during the first half of the nineteenth century the inquilinaje system underwent a drastic change: peonization, that is, it became a form of resident peonage, and that by 1870 the majority of inquilino families [were] families of permanent peons. The author uses the Viluco case, the same hacienda Bauer discussed using the BSNA 1872 report to demonstrate the extension of inquilinaje. However, Salazar's notion of the inquilino falling into the ranks of peonage comes from Lloyd (1915: 114-15) who characterized the inquilino as a farm-labourer, stating that Until perhaps thirty years ago he was a simple serf, with innumerable duties and few rights; peonaje, the system which enveloped him and gripped him remorselessly, has been described as "wage slavery without the wage", and in those days such a description did it no injustice.

On balance, there was not much really new in Salazar's treatment of the hacienda system and rural labor in the export-led growth phase, both in terms of arguments and empirical material. In fact, his work reiterates ideas proposed by either Bauer or Kay, the main difference being his pseudo-theoretical language compounded by the use of ill-defined terms (bajo pueblo, labradores, campesinado, for instance), instead of analytical categories articulated in a recognizable conceptual approach. Likewise, there is almost no information on actual rural estates, except for observations taken from travelers' accounts and the like; thus, the hacienda system is dealt with from the outside. In addition, given its limited data, this account of rural society in the period of agrarian expansion is confined to Central Chile and does not go beyond the 1870s. 
Although conceived as an introduction to Chilean rural history, and thus geared for a non-specialist audience, anthropologist José Bengoa's works are also conventional reiterations. Moreover, Bengoa's works are flawed by his selective use of non-representative evidence, impressionistic treatment of topics, and self-contradicting interpretations. A salient element in those works is the oversimplification of arguments that Bauer had already offered, particularly on rural labor systems, agrarian capitalism, and social conflict in rural society. The author restated what Bauer proposed as extension of inquilinaje, calling it re-inquilinización; further, instead of providing a documented analysis of rural labor, his treatment of the subject is, basically, a description of the landed oligarchy's views on rural workers. Bengoa also produced a simplistic version of one of Bauer's most debatable arguments: the absence of social conflict in rural Chile until after the 1920s. Bauer did not research the subject but pointed to increasing social tensions in the late nineteenth century, and labor movement activists' efforts to bring modern social conflict to the countryside after the First World War. Moreover, Bengoa (1990a: 156-57) held that labor systems in the La Frontera region were similar to those in Central Chile, especially the inquilinaje, to the point of stating that it seemed as if a part of the central region of the country had been moved to the area close to Temuco (1990a: 157). However, Bengoa's lack of rigor in using his only source misled him to quote uncritically a report on fundo Poco a Poco, where the author, a graduating agronomist, (Baeza, 1910: 25-6) plagiarized whole paragraphs on both the inquilinos and peons in Central Chile, not in La Frontera, written 35 years earlier by Juan N. Espejo (1876: 139-41) for the so-called Primer Congreso Libre de Agricultores (1875) ${ }^{6}$.

Bengoa did not study rural conflict either, but reduced the matter to the absence of peasant revolts, maintaining that rural workers remained a quiet and submissive peasantry until the twentieth century (Bengoa, 1988). Moreover, in the reprint of this work (Bengoa, 2015), such notion grows into a pax hacendal, which, however, is neither substantiated, nor plausible at all. In fact, the author ignored Brian Loveman's (1976) fundamental contribution: modern social conflict began taking place in the Chilean countryside as the first wave of rural workers' mobilization between 1919 and 1927. Furthermore, Bengoa also ignores that, before mass politics reached the countryside, Chilean rural workers contested landowners' power employing everyday forms of resistance, as discussed in recent works on Central Chile (Robles, 2017).

6. KLubock (2014: 320, note 18), who also used this report, did not notice the plagiariasm and Bengoa's uncritical use of the source, for he writes fosé Bengoa also discusses this thesis in a very useful analysis of southern labor relations. 
In addition, Bengoa has produced self-contradicting opinions on the development of agrarian capitalism in Chile, which is related to his view of inquilinaje as an obstacle to capitalist development. Thus, the author argued that the 1880-1930 period witnessed incomplete capitalist agrarian development [because] inquilinaje was maintained, that is, there was no modernization in labor relations (Bengoa, 1988: 8). However, since he did not examine changes in labor regimes, he missed the process of proletarianization of the inquilinaje, which began in the 1870s in Central Chile. At the same time, Bengoa does not take into account that, especially on large haciendas, wage laborers outnumbered inquilinos, as shown by data available in his own work (Bengoa 1990b: 168-70). Thus, his views rest on a narrow conceptualization of proletarianization, as Kay (1977) pointed out about Bauer's interpretation. Yet, in the 2015 reprint of his works, which features as a new chapter an article on hacienda Quilpué originally published in 1990, the author reiterates that modern relationships do not expand in the countryside, neither capital nor capitalism expand (Bengoa, 2015: 236-37). This opinion is consistent with his idea that the trend towards agrarian capitalism stagnated after the 1930 crisis and until the 1960s: a small group of fundos [...] became agricultural enterprises, while those that had not achieved significant modernization retrogressed into agrarian traditionalism (Bengoa, 1990a: 8, 21112). However, this assertion contradicted what the author stated in an earlier work. Discussing trends in the period between 1930 and the agrarian reform, he stressed that Haciendas modernized and specialized production [and] labor was increasingly becoming wage labor, so that there were large regions of the country where the trend pointed to the elimination of the inquilinaje. Thus, although There were, of course, other areas where until the 1960s no cash payments existed [...] the general trend was different. The number of inquilinos and obligados diminished, and that of voluntarios or rural waged laborers increased (Bengoa, 1983: 163-64).

In sum, works by Chilean authors focused on the same process that Bauer and Kay had discussed in the previous decade ${ }^{7}$. Despite their differences, these new renditions reiterated or oversimplified the foundational interpretations' main arguments. Further, Bengoa's self-contradicting versions on the development of agrarian capitalism are but another indication that this subject was long neglected in Chilean economic and agrarian historiography. Indeed, Kay's alternative interpretation asserting that agrarian capitalism gained traction after 1930 remained until recently "a path not taken" by historians of rural Chile.

In addition to the "conventional reiterations" in the history works that we have just examined, in the 1980s and 1990s there were other developments in the study of Chilean

7. Bauer himself noted these variations on both his own and Kay's interpretations in the works Chilean scholars published in the 1980s; see BAUER (1995). 
rural society and agriculture that should be mentioned. A great deal of the research carried out at NGOs based in Chile dealt with recent processes, that is, the unraveling of the agrarian reform and the so-called counter reform imposed by the military dictatorship. Likewise, social science scholars examined the unprecedented impacts of the "neoliberal model" on Chilean agriculture and rural society. Thus, Gómez y Echenique (1988) pioneered the analysis of the "agricultural modernization", that is, the emergence of new sectors of capitalist agriculture, like fruticulture, that proved highly successful in the international market. As discussed in several works by Valdés $(1988,1992)$, another important development was the study of changes in rural labor, especially the formation of a new rural proletariat comprised of mostly women residing in villages and towns, and bused to plantations and packing facilities. At the same time, scholars studied rural women's life stories, to examine their experience in the hacienda-centered rural society (Valdés, 1988). If these, mostly sociological, works exposed the negative social consequences of the socalled neoliberal model, an outstanding work by agricultural economist Lovell ("Tu") Jarvis (1981) critically examined the performance of the agricultural sector under military dictatorship. Jarvis demonstrated that using "severely biased" data produced by Chile's Oficina de Planificación Nacional (ODEPLAN), the military dictatorship overstated agricultural growth in national accounts from 1973 to 1981, as an indication of the positive effects of the government's policies. Instead of the dynamic sector that the dictatorship's data showed, the truth was that even according to official corrected data, the sector was growing very slowly, and the use of modern, purchased inputs had been declining (Jarvis, 1981: 34-5). Finally, an important contribution to the study of Chilean agriculture and rural society was Kay and Silva (1992), an edited volume particularly informative for the neoliberal period.

\section{A REVISIONIST AGRARIAN HISTORIOGRAPHY}

In the last 15 years, a new, revisionist agrarian historiography revitalized the study of Chilean rural history, by critically examining the interpretations on the agrarian expansion (1870-1930) proposed in previous works. Thus, Robles (2002) analyzed the economic performance of the agricultural sector, transformations in the large estate, technological innovations, primarily mechanization, and the agrarian expansion's impact on rural labor. At the same time, the author reconsidered Cristóbal Kay's hypotheses, and adopted the latter's hacienda system approach. As a whole, Robles (2002, 2009a) proposed an alternative interpretation of the agrarian expansion, regarding it as the first phase of the development of agrarian capitalism in Central Chile's hacienda system. Resting on selective mechanization and irrigation, the expansion of the "landowner enterprise" resulted in the marginalization of inquilinos' precarious "peasant enterprises", and gradual prole- 
tarianization of inquilinaje. This process was part of a general trend towards the diffusion of wage labor, for waged peons outnumbered inquilinos; as a result of these trends, in the 1920s a rural working class was emerging, primarily on large haciendas located next to large cities.

Revisionist works have also shed new light on technological change during the agrarian expansion, particularly mechanization, a subject not thoroughly researched in the earlier historiography (Hernández, 1966; Bauer, 1975). The introduction of agricultural machinery was carried out by a sector of "progressive landowners", through an exchange of practical knowledge with the foreign firms that dominated the importation of farming equipment (Robles, 2007). That interaction also involved agricultural experts and institutions, which contributed to the development of a mechanical culture in the countryside, thus facilitating the adoption of the new technology. The experimental importation of agricultural machinery in the 1840 s built up into a "first wave" of mechanization in the export booms of the 1850-90 period, when Chile exported wheat first to California, Australia and, then, England. As landowners needed to solve recurring labor shortages during the harvest seasons, the use of machines increased on properties in which the area under cultivation was considerable, and in the most labor-demanding operations, above all, the harvest of wheat. In the 1870 s, labor-saving machines, that is, reapers, mowers, and, above all, threshers, were extensively used to carry out the harvest of cereals and fodder crops (Robles, 2018b). After the 1880s, mechanization proceeded along with the increasing orientation of the agricultural sector to the internal market. By 1910, iron plows, a variety of tilling instruments, and harvesting machines were widely employed in the production of cereals and fodder crops, especially in Central Chile and La Frontera region. Moreover, beginning with the introduction of the steam engine in the 1850s, large landowners and lesser agriculturists introduced a series of power sources, which coexisted until First World War when the tractor made its debut in the Chilean countryside (Robles-Ortiz, 2009a).

The revisionist historiography also examined the economic performance of the agricultural sector in the period of agrarian expansion, $c .1870-1930$. Since there was no analysis of agriculture's economic trends before 1930, this was a conspicuous lacuna in economic history; even so, general interpretations portrayed a declining sector after the 1874-78 economic crisis. In contrast, Cariola and Sunkel (1982) suggested that growth of the domestic demand stimulated agricultural expansion and diversification in the period of export-led growth based on the nitrate industry, c. 1880-1930. However, scholars of Chilean agriculture ignored this significant contribution. Yet, adopting Cariola and Sunkel's hypothesis, and constructing a whole new set of quantitative data series, Robles (2009b) established agriculture's macroeconomic trends. The sector underwent a considerable expansion, which reflected in the spectacular increase in the area under cultivation and 
in the output in all the crop groups, especially cereals, above all wheat, by far the most important single crop. Significantly, land productivity in wheat slightly increased over this long period of sustained expansion of the area under cultivation, which is indicative of the impact of biological innovations introduced in Chilean agriculture before 1930. The main implication of this new view of agriculture's economic performance is that the sector's slower growth after 1930 was not the consequence of a supposedly stagnant sector prior to the Great Depression, but provoked by other factors, especially economic policy aimed at fostering the industrial sector.

In addition, institutional studies in the revisionist historiography expanded the study of the Sociedad Nacional de Agricultura (SNA), established by upper-class landowners in 1869 to foster the modernization of agriculture (Carrière, 1981; Wright, 1982). This dimension of SNA's action did not receive further attention in decades, perhaps because of its role as a political right-wing actor in twentieth-century politics. More recently, however, Robles (2007) argued that SNA's nineteenth-century positivist modernization project not only sought to promote mechanization and create agronomic institutions, but also to prevent class conflict in rural society, by regulating inquilinaje, attracting European colonists, and reducing the rural proletariat of peons. The author also analyzed SNA's role as a pressure group in the economic policy debate, especially regarding tariff reforms (2009c). Further, this institutional research studied SNA's agrarian ideologues, knowledgeable analysts who represented elite landowners' interests in the public sphere, above all the impressive Julio Menadier, editor of the SNA's bulletin (Robles, 2010b, 2012, 2016).

Furthermore, the new historiography on the agrarian expansion (1870-1930) also reappraised the possibilities that existed for agricultural modernization in Chile's underdeveloped economy, by analyzing the so-called fruit industry; thus, examining the experience of Chilean agriculture in the broader context of the long-term development of Mediterranean agrarian systems (Robles, 2010a). In the early twentieth century, along with a modern fruit-canning industry, Chile witnessed the formation of a fruit-growing sector, which Chilean "growers" envisioned as a "South American California". Yet, despite its expansion and growers' expectations, the "fruit industry" did not emerge as a significant export sector. Export markets were indispensable for the expansion and specialization of fruit growing. However, Chilean growers developed orchards primarily geared for the domestic market, and which still in the 1920s were not yet fully specialized. Shifting to "export varieties" required capital, expertise, and biological inputs that many fruit growers could not afford. Yet, the incorporation of expertise-supplying state institutions was insufficient to correct inadequate fruit farming practices. Further, the lack of appropriate transportation for safely shipping highly perishable goods like fresh fruits proved a decisive obstacle to the success of the fruit export sector. 


\section{RECENT AND CURRENT RESEARCH}

\subsection{Economic history and agrarian capitalism}

Long neglected, agrarian capitalism has received more attention in recent publications, both in history and social science works. The latter, however, employ a general approach and outdated secondary literature, and thus can hardly substitute for historical analysis of such a long-term process. As part of an attempt to reappraise the agrarian reform, Chilean geographer Antonio Bellisario discussed agrarian capitalism in his doctoral dissertation (2002), subsequently published in several articles, first in English (2006, 2007a, 2007b) and then in Spanish versions (2013a, 2013b). Bellisario argued that before the implementation of the agrarian reform, Chile had not finished its transition to modern capitalism [sic] due to the persistence of the antiquated hacienda system. The process of land reform, which the author sees as taking place from 1964 to 1980, completed the long-postponed transition (Bellisario 2006: 167; 2013b: 342). This argument rests on a comparison of the number of inquilinos between the 1955 and 1965 censuses, and the land they held as land allotments ( $\mathrm{ra}$ ciones de tierra), which grew by $2.6 \%$, the author estimates using a data sample from previous researchers' works. Such figures would demonstrate the unexpected structural continuity of the hacienda system, instead of supporting Kay's thesis of rapid disintegration and proletarianization of its labor force in the 1950s and 1960s (Bellisario, 2006: 185-87).

However, the author's treatment falls short from being an analysis of the development of agrarian capitalism, a process that started in the late nineteenth century. It would have hardly progressed considerably in such a short period, as that between the 1955 and 1965 censuses. Further, Bellisario sees the inquilinaje system as an unchanging pre-capitalist social relationship, failing to take into consideration that, according to the data that he examines, only 30 percent of inquilinos' income was obtained as producers. Thus, inquilinos were resident workers, dependent on wages and perquisites calculated in monetary terms. This rather proletarianized inquilinaje, it is argued elsewhere (Robles, 2009a), resulted from the gradual changes it underwent from the late-nineteenth century onwards. More significantly, the author does not consider the increase in the number of wage laborers as indicative of agrarian capitalism, even though those workers came to be twice as many the inquilinos, a trend in the agricultural workforce that was long developing, and thus recorded for the country as a whole as early as 1935, in that year's agricultural census (Robles, 2009a: 519).

Unlike social science studies, recent research in history has emphasized the specificity with which agrarian capitalism unfolded in Chile's different regions. Indeed, except for Central Chile (Robles \& Kay, 2018), the lack of a substantial body of studies on the coun- 
try's distinctive rural societies has been a characteristic of Chilean historiography. Thus, still today, there is no economic or agrarian history of La Frontera and Llanquihue regions, two of the most important Chilean rural societies. However, recent research on $\mathrm{La}$ Frontera region, where agrarian capitalism began developing after the military occupation of the Mapuche territory (1863-88), shows that backed by the state, a new class of landowners created a capitalist agriculture via a regional variant of the landowner road (Robles, 2020a). In that process, landowners formed a new hacienda system, adapted to the region's ecological conditions. Since forests covered vast areas, sharecropping made it possible to clear or improve land to form fields for growing crops; thus, the rural estate would transition from the exploitation of native forests to large-scale cereal growing and cattle raising. From the beginning, its workforce included waged laborers, mostly migrants that ultimately failed in their pursuit of becoming a land-owning peasantry or a class of small farmers. Wage labor, then, was a constitutive social relationship of the Frontier rural estate.

The study of the agricultural sector in the twentieth century, as well as developments in specific sectors and activities, have also received attention by scholars working from different approaches, both in economic and agricultural history. Economic historian José Díaz (2006) assessed the sector's performance in the period between Great Depression and the agrarian reform, thus revisiting the issue of "agricultural stagnation". Contrary to conventional wisdom, Díaz's thoroughly researched work established that land productivity did not decrease, and even increased moderately in the 1950s. However, exports did decrease; but this can be attributed to the negative impact of economic policy. The development of capital intensive activities, and new dimensions of technological innovations in the agricultural sector, broadly defined, have been discussed in recent works. Focusing on the so-called Nitrate Era (1880-1930), Bibiana Rendón (2015) has revealed a vibrant fruit-canning industry, which benefited from protectionist policies, and supplied both the domestic and external market. Along with expanding our knowledge of the industrialization process, and its relationship with the commercial horticultural sector, this pioneering work has also started a promising new research area in business history of agriculture. Similarly, through a transnational approach to the circulation of expert knowledge, Eduardo Gallardo (2017) researched the modernization of the livestock sector from 1917 until 1939 in Osorno, southern Chile, where the German-Chilean landowning elite benefited from close relationships with German institutions. Thus, prominent local scientists and entrepreneurs introduced improved cattle breeds and updated production methods, such as "model slaughterhouses". Further, Gallardo $(2012,2016)$ studied the role of local agronomy scholars in the development of both farming and livestock raising in southern Chile. 
In addition, expanding the study of agricultural mechanization, Robles (2020) analyzes the introduction of the tractor as a technological learning process in Chile, c. 191035. Enterprising landowners and state experts began to test tractors as early as 1907, primarily as a solution to "poor plowing" and low productivity. Agriculturalists learned to determine what models would be more suitable to Chile, and thus they overcame the initial failure of steam caterpillar or "mammoth" tractors, to adopt wheel, light gasoline models marketed in the 1920s. By 1935, the majority of the existing tractors was in Central Chile, not in the southern provinces of German colonization that American geographer George McBride (1938) regarded as "progressive lands". Dealing with a later period, Rojas (2016) summarizes an official report showing that the stock tractors increased significantly in the 1950s and 1960s, and, unsurprisingly, this technology was introduced primarily by large landowners.

In contrast, the study of agriculture at a regional level has not yet been carried out adequately. Thus, a great deal of the rural history of the Frontier region is still to be found in the unpublished doctoral dissertations by Castillo (1983) and Ruiz-Esquide (2000), while Blancpain's (1974) detailed work on the German colonization remains the main source for the development of Llanquihue region's rural society and economy. Further, the same can be said about the valuable study by Gloria Gallardo (1998) on the agricultural communities of the Norte Chico region. Also worth-mentioning, Otero (2006) vividly documented the impact of human settlement on southern Chile's forests. In the only recent study that makes a significant contribution, Klubock (2014) discussed forestry development in southern Chile, attempting to combine social and ecological history. The author documents how the reduction of the Mapuche communities led to a critical loss of land, while the Chilean state facilitated the fraudulent formation of large estates in the frontier territory (Klubock, 2014: 51).Yet, as Robles observed (2015) this work offers a simplistic account of frontier agrarian development: absentee landowners set forests on fire to clear land for wheat production, while sharecroppers destroyed the soil, since they had neither interest in preserving the land, nor capital to invest in fertilizers. From a completely different perspective, Tinsman (2014) revealed the long-term exchange of new crops, scientific knowledge, and technologies that took place between California and Chile from the 1960s to present day's "Davis Boys", that is, the Chilean experts trained at the University of California, Davis who were so influential in what we may call the "Californization" of Chile's modern, neoliberal agricultural sector. 


\subsection{Rural politics and agrarian reform}

The study of rural politics has been one of the least developed areas in Chilean historiography. As we saw, Arnold Bauer did not study social conflict in nineteenth-century rural society, and Brian Loveman's (1976) pioneering work on rural conflict in the twentieth century remained virtually ignored until recently. Moreover, despite its political relevance, even the agrarian reform was superficially treated as a dimension of national politics in general political history works by Chilean scholars. In contrast, sociopolitical conflict was the core subject in works that foreign and Chilean scholars produced during the agrarian reform period, and immediately after the 1973 military coup d'état.

Yet, recent scholarship has expanded Chilean historiography's treatment of rural politics, particularly social and political conflicts in twentieth-century rural society, especially during the agrarian reform. In light of the transformations that rural labor systems underwent in the agrarian expansion, Robles (2009a) reexamined rural strikes in the first wave of unionization (Loveman, 1976), arguing that those forms of modern collective action were carried out by rather proletarianized inquilinos and wage peons, that is, an incipient rural working class that was becoming an active part in the labor movement. Further, the author's most recent work (Robles, 2018b), focusing on political practices in rural society, documented how, before the era of mass politics, rural workers did confront landowners or, rather hacienda administrators, by means of several forms of everyday resistance, of which incendiarism was prominent. Therefore, in the late nineteenth and early twentieth centuries there was also a transition in the form of social conflict in rural society, from the micro-politics of everyday resistance to collective action.

After being a neglected subject, the agrarian reform, in turn, gradually regained academic interest in Chilean historiography. Initially, thanks to two pioneering studies on important social actors that previous scholarship had marginalized, namely, women and the Mapuche people. From a feminist labor history perspective, Heidi Tinsman (2002) stressed that gender inequality was a defining element of the agrarian reform, as women were excluded from the asentamientos created after the expropriation of landed estates, and state programs reinforced their role in the domestic sphere. However, the author shows, women did become active participants in the politics of agrarian reform in a variety of ways, from organizing soup kitchens (ollas comunes) to joining radical mobilization and carrying out land takeovers. Further, valuable works have dealt with the agrarian reform from the perspective of the Mapuche people. Mallon (2004) discussed that process as an experience of fleeting prosperity; Correa, Molina andYáñez (2005) provided an informative discussion of expropriations of landed estates, the role of Mapuche communities, and the agrarian reform's impact on land redistribution. 
In addition, recent research has definitely re-established politics as the main perspective from which to study the agrarian reform, and has also placed this process as the center of analysis of Chile's recent political history. By focusing on a local society in southern Chile, Robles (2011) studied the agrarian reform as a social conflict, whereby radical social mobilization led to politicization and increasingly violent polarization in rural society during the Popular Unity Government (1970-73). Further, as the author documents for forestry workers in Panguipulli, who adopted land takeovers (tomas de fundos) as a strategy in the struggle for land and power, and joined the local expression of an emerging "new left", radical rural mobilization was the basis of the "revolution from below" that challenged the "Chilean road to socialism" in the countryside and strongly influenced the trajectory of the national political conflict (Robles, 2018a).

Foreign scholars too have made significant contributions to the study of the "politics of agrarian reform", by considering new dimensions of political conflict, revisiting topics in light of new information, and bringing diverse theoretical approaches. Adopting an institutional approach, Oscar Oszlak (2016) traced landowners' political response, by focusing on the SNA and using relevant information from its board of directors' meetings for the period 1958-69, the written records of which the author was allowed to consult in 1970, while conducting research on business organizations in Latin America. The author examined SNA's internal debate on strategies to confront agrarian reform, and documented how that organization led landowners' opposition to the Popular Unity. Reexamining radical rural mobilization by Mapuche communities in Cautín province, one of the centers of rural conflict during the agrarian reform, Jesús-Ángel Redondo (2017) provided a more nuanced account of that experience. A detailed inspection of local newspapers revealed that half of the land takeovers were carried out by non-Mapuche peasants, while several political organizations of differing political persuasions, not just those of the "revolutionary left", promoted rural mobilization. In addition, violent confrontation occurred in rather few cases, which resulted from the armed reaction of large landowners seeking to take back occupied estates. Daniel Carter (2019) has just analyzed Cautín landowners' violent resistance to agrarian reform. Using written sources and oral interviews, he explains how they adapted the civilisation-versus-barbarism ideology to the prevailing anti-communist discourse, and coordinated violent resistance through extremist right-wing organizations, whose actions anticipated the military coup of September 1973 (Carter, 2019: 28).

Most recently, Brazilian scholars have directed their attention to the Chilean agrarian reform, a promising development for Chilean historiography since these researchers analyze the Chilean experience informed by their previous study of other Latin American agrarian reforms. This is especially the case of historian Vanderlei Vazelesk's explicitly com- 
parative work on the political conflict throughout the agrarian reforms (2017). Joana Salém (2020) examines the political-pedagogical strategies for "peasant training" (capacitación campesina), that Chilean and foreign actors implemented in their confrontation over peasant cultural change, in the "Chilean roads", first to capitalism and then socialism, under the Christian Democratic government (1964-70) and the Popular Unity, respectively. Daniel Borges (2020) discusses rural workers' challenge to landowners' power, as the basis for the rise of peasant activism, by which Chilean campesinos defended their interests as a social class both in existing institutional political spaces and through their own new forms of political action. In response, landowners reformulated their political strategies to disarticulate rural workers' political expressions, which they ultimately accomplished with the 1973 military coup.

The agrarian reform has also been revisited in a series of testimonies and memoirs, by government actors, political militants, and former landowners. As some of these works show, conflicting memories of the agrarian reform matter in on-going political conflicts in Chilean society, both over recent history and present-day issues. Thus, anthropologists Calderón and Fahrenkrog (2012) examined the experience of rural workers in the Norte Chico region. In contrast, Cousiño and Ovalle (2013) gathered several interviews with elite landowners, whose recollections are, unexpectedly, highly critical of the land reform, especially under the Popular Unity. If some actors may have demonized the agrarian reform, former CORA Vice-President and Christian Democratic Senator Rafael Moreno (2013), who also became a leading opponent to the UP, stresses its positive impact in transforming rural Chilean society and agriculture. In turn, José Manuel Bravo (2012), offers an illuminating account of the political conflict under the Popular Unity, which he experienced as a forestry worker and then as new-left revolutionary in Panguipulli, southern Chile, where he took a leading role in the radical mobilization that pressed the government to speed up the agrarian reform. The first Minister for Agriculture in that government, Jacques Chonchol, dialogues with Claudio Robles (Chonchol \& Robles, 2016), to recall his twentieth-century life as a Christian, non-Marxist revolutionary whose political career took him to implement the agrarian reform of the "Chilean road to socialism". These testimonies and memoirs, it must be noted, were produced before the fiftieth anniversary of Law no. 16,640 of Agrarian Reform (1967). In contrast, the commemorative opportunism sparked by the event did not produce works of significance, except for the volume edited by Rojas and Manríquez (2017), which provides informative analyses of the agrarian reform; and Faiguenbaum (2017), an informative history of INDAP, the Institute for Agricultural Development. 


\section{NOTES FOR FURTHER DEVELOPMENT AND RESEARCH}

Suggesting topics for a research agenda, and briefly discussing how future research should be conducted, seems a useful way to conclude this survey of Chilean agrarian historiography. First and foremost, Chilean agrarian historians should carry out their research paying close attention to, and in dialogue with, other rural historiographies in the international academic community. A fruitful relationship with researchers abroad would facilitate the introduction of innovative theoretical and methodological approaches, but also historiographic debates, which would certainly enrich the study of Chile's still insufficiently analyzed rural history. Moreover, by taking part in the agrarian history international community, Chilean scholars could be able to study Chilean rural history in ways that would make it relevant for foreign researchers. Thus, scholarship on rural Chile would not only be "useful" for comparative purposes, but also by offering transportable knowledge, that is, insights that can be adopted, or adapted, to study other countries. A first practical, indispensable step for Chilean scholars is reading, and writing for, international journals, especially those that are published in English, or those that publish articles in more than one language.

At the same time, Chilean agrarian historiography would further develop if historians understand it as a complex field of scholarship. This may seem certainly inappropriate to say for a historiography that has not even yet developed in the "strict" (not "narrow") sense of the so-called cows-and-plows agricultural history. However, the study of rural history will be much more productive if agrarian historians are determined to plow all sorts of fields. Thus, rural historians would deal with a wide range of topics, processes, and problems, from farming methods to politically charged cultural representations of the countryside, the study of which is, indeed, relevant for society, not just for historians. Rural history would be better also if historians study it considering all sorts of questions, not just "technical" ones. Thus, rural history would also significantly contribute to explain Chilean society, not "just the past".

Moreover, advancing rural history in Chile requires, perhaps more than in other disciplinary areas, to confront prejudices, and consider how scholars' political opinion plays a role in research. Chilean historiography has concentrated on the so-called grandes terratenientes, and the dominant view stresses their role as a conservative, often reactionary, political actors opposing social change and democratization. The aggressive opposition of their business organizations and political parties to the agrarian reform, and their leading role among the social and political forces violently mobilized against the "Chilean road to socialism" are, many would agree, indisputable expressions of the role that the "landed oligarchy" has played in politics. From an agrarian-history disciplinary perspective, the de- 
nunciation of large landowners has been quite negative. It has given currency to political biases against agrarian history, not only as if it were the study of prosaic technical matters, but also as if rural historians' interest in agricultural history were per se as conservative as the landowners themselves. Indeed, political biases and plain ignorance still are obstacles to teaching and researching agrarian history, particularly in certain academic departments.

As a result, Chilean historiography as such has neglected, or poorly studied, many rural history subjects and topics. One of those is the very structure of a rather complex rural society. Thus, there is little research on the different classes and sectors of landowners and agriculturalists of Chile's diverse rural societies. Indeed, not even Central Chile's large landowners, usually treated as powerful and retrograde latifundistas, and perhaps the most detested social class in Chilean historiography, have been thoroughly studied as "agriculturalists". One of the main consequences of lack of research on agriculturalists, large landowners or otherwise, is the still insufficient knowledge on the development of agriculture and its different units of production. Thus, we still know little on farming methods for the different crops, the evolution of agronomic culture, the trajectory of specific sectors and activities, or the dynamics and trajectories of different types of units of production, among other relevant topics. At the same time, and as a consequence, we still are far from researching well the experience of other social actors, rural workers of many sorts, for instance, in the realms of work, labor conflict, and power relations in the countryside.

Finally, I would suggest some more concrete actions to further develop agrarian history. Chilean universities and scholars should work towards the construction of agrarian histories of the distinct regions and rural societies that have developed in Chile. They have formed through different processes, have their own historical actors and structures, and have certainly had different trajectories and conflicts. In addition, Chilean historiography needs to be given more representation in the educational system and its institutions. It should be taught not only in history programs, but also in economics, agronomy, and sociology programs, for instance. Likewise, rural history needs more institutional development, such as its own conferences and journals. This is, precisely, what the Centro de Estudios de Historia Agraria de América Latina (CEHAL) is doing, both through the Agrarian History International Colloquia and the new journal Historia Agraria de América Latina (HAAL). Further, agrarian historians need to protect and preserve Chile's documentary rural patrimony; otherwise, it will continue fading away, and latterday scholars will encounter even more obstacles to study rural history ${ }^{8}$.

8. The outstanding Chilean geographer Rafael ('Don Rafa') Baraona made an invaluable contribution in this regard with the Biblioteca Conmemorativa José María Arguedas, comprised mostly of his own library, later donated to Chile's National Library. 


\section{ACKNOWLEDGEMENTS}

The author is grateful for the comments received on a preliminary version of this article presented at the conference "Transiciones en la agricultura y la sociedad rural. Los desafios globales de la historia rural", held in Santiago de Compostela in 2018; he also thanks the journal editors and reviewers for their helpful suggestions.

\section{REFERENCES}

ARANDA, S. \& MARTíNEZ, A. (1970). Estructura económica: Algunas características fundamentales. In A. PINTo et al. (Eds.), Chile, hoy (pp. 116-51). México, DF: Siglo XXI. BAEZA, E. (1910). Monografía del fundo Poco a Poco de Temuco. Santiago: Impr. Universal.

BARAONA, R. (1965). Una tipología de las haciendas de la sierra ecuatoriana. In O. DELGADO et al., Reformas agrarias en la América Latina: Procesos y perspectivas (pp. 68996). México, DF: Fondo de Cultura Económica.

BAUER, A. J. (1969). Chilean Rural Society in the Nineteenth Century. Unpublished doctoral dissertation. Berkeley: University of California.

BAuER, A. J. (1971). Chilean Rural Labor in the Nineteenth Century. The American Historical Review, 76 (4), 1059-82.

BAUER, A. J. (1975). Chilean Rural Society from the Spanish Conquest to 1930. Cambridge: Cambridge University Press.

BAUER, A. J. (1994). La sociedad rural chilena: Desde la conquista española a nuestros días. Santiago: Andrés Bello.

Bauer, A. J. (1995). Landlord and Campesino in the Chilean Road to Democracy. In E. Huber \& F. SAFFord (Eds.), Agrarian Structure \& Political Power: Landlord \& Peasant in the Making of Latin America. Pittsburgh/London: University of Pittsburgh Press.

BAuer, A. J. (2012). Time's Shadow: Remembering a Family Farm in Kansas. Lawrence: University of Kansas Press.

Bellisario, A. (2002). The Land Question: Statist Planning and Capitalist Development in the Chilean Countryside. Unpublished doctoral dissertation. Los Angeles: University of California.

Bellisario, A. (2006). The Chilean Agrarian Transformation:The Pre-Agrarian Reform Period (1955-1965). Fournal of Agrarian Change, (6) 2, 167-204.

Bellisario, A. (2007a). The Chilean Agrarian Transformation: Agrarian Reform and Capitalist "Partial" Counter-Agrarian Reform, 1964-1980. Part 1: Reformism, Socialism and Free-Market Neoliberalism. Fournal of Agrarian Change, (7) 1, 1-34. 
Bellisario, A. (2007b). The Chilean Agrarian Transformation: Agrarian Reform and Capitalist "Partial" Counter-Agrarian Reform, 1964-1980. Part 2: CORA, Post-1980 Outcomes and the Emerging Class Structure. fournal of Agrarian Change, (7) 2, 14582.

BELLISARIO, A. (2013a). La reforma agraria chilena: Reformismo, socialismo y neoliberalismo, 1964-1980. Historia Agraria, (59), 159-90.

Bellisario, A. (2013b). El fin del antiguo régimen agrario chileno (1955-1965). Revista Mexicana de Sociología, (75) 3, 341-70.

BENGOA, J. (1983). El campesinado chileno después de la reforma agraria. Santiago: Ediciones Sur.

BENGOA, J. (1988). El poder y la subordinación. Santiago: Ediciones Sur.

BENGOA, J. (1990a). Haciendas y campesinos. Santiago: Ediciones Sur.

Bengoa, J. (1990b). Una hacienda a fines de siglo: Las Casas de Quilpué. Proposiciones, (19), 142-72.

BengoA, J. (2015). Historia rural de Chile central. I: La construcción del Valle Central de Chile. Santiago: LOM.

BlancPain, J. P. (1974). Les Allemands au Chili: (1816-1945). Köln: Böhlau.

BoRgES, D. (2020). A disputa pela reforma agrária no Chile: Socialismo, participação camponesa e mobilização proprietária (1967-1973). Unpublished doctoral dissertation. Rio de Janeiro: Universidade Federal do Estado do Rio de Janeiro.

Bravo, J. M. (2012). De Carranco a Carrán: Las tomas que cambiaron la historia. Santiago: LOM.

CALderón, M. \& FAhrenkrog, K. (2012). Memorias de la reforma agraria: La lucha por la tierra en el valle de Longotoma. Santiago: LOM.

Cariola, C. \& Sunkel, O. (1982). Un siglo de historia económica de Chile, 1880-1930: Dos ensayos y una bibliografía. Madrid: Ediciones de Cultura Hispánica.

CARRIÈRE, J. (1977). Landowners and the Rural Unionization Question in Chile: 19201948. Boletín de Estudios Latinoamericanos y del Caribe, (22), 34-52.

Carrière, J. (1981). Landowners and Politics in Chile: A Study of the "Sociedad Nacional de Agricultura", 1932-1970. Amsterdam: Centro de Estudios y Documentacion Latinoamericanos.

CARTER, D. (2019). Violence, Ideology and Counterrevolution: Landowners and Agrarian Reform in Cautin Province, Chile, 1967-73. Fournal of Latin American Studies, 51 (1), 109-35.

Castillo, H. (1983). Agrarian Structures in a Region of Recent Colonization: La Frontera, Chile, 1850-1920. Chapel Hill: University of North Carolina.

Correa, M., Molina, R. \& YÁÑEz, N. (2005). La reforma Agraria y las tierras mapuches: Chile 1962-1975. Santiago: LOM. 
Cousiño, A. \& Ovalle, M. A. (2013). Reforma agraria chilena: Testimonios de sus protagonistas. Santiago: Memoriter.

CHONCHOL, J. \& RoBles, C. (2016). Facques Chonchol: Un cristiano revolucionario en la política chilena del siglo XX. Santiago: Universidad Finis Terrae.

DíAZ BAHAMONDE, J. (2006). El desarrollo frustrado revisado:Tres estudios sobre la economía chilena, 1928-1958. Unpublished doctoral dissertation. Alcalá: Universidad de Alcalá.

EsPejo, J. N. (1875), El trabajador rural. In Primer Congreso Libre de Agricultores (pp. 140151). Santiago: Imprenta de la República.

Faiguendaum, S. (2017). Toda una vida: Historia de INDAP y los campesinos (19622017). Santiago: Instituto de Desarrollo Agropecuario/Organización de las Naciones Unidas para la Alimentación y la Agricultura.

Gallardo, E. (2012). El ingeniero agrónomo Dr. Adolfo Matthei y su rol en la agricultura en Chile y Osorno (1925-1939). Osorno: Universidad de Los Lagos.

GALLARDO, E. (2016). Modernización ganadera bovina en el sur de Chile: El rol del médico veterinario Alfredo Neumann, Osorno, siglo xx. História: Debates e Tendências, 16 (1), 183-96.

GALLARDO, E. (2017). Modernización ganadera en el sur de Chile: Osorno y sus contactos chileno-alemanes en perspectiva transnacional, 1917-1939. Unpublished doctoral dissertation. Berlin: Freie Universität Berlin.

Gallardo, G. L. (1998). Communal Land Ownership: Remnant of the Past?: A Historical-Sociological Study of the Agricultural Communities of Chile's Norte Chico:The Case of Canela Baja (1600-1998). Uppsala: Uppsala University Press.

Gómez, S. \& ECHENIQUE, J. (1988). Agricultura chilena: Las dos caras de la modernización. Santiago: Facultad Latinoamericana de Ciencias Sociales/AGRARIA.

Hagen, W. (1998). Village Life in East-Elbian Germany and Poland, 1400-1880. In T. ScotT (Ed.), The Peasantries of Europe: From the Fourteenth to the Eighteenth Centuries (pp. 145-189). London/New York: Longman.

HERNÁNDEZ, S. (1966) Transformaciones tecnológicas en la agricultura de Chile central: Siglo xIx. Cuadernos del Centro de Estudios Socioeconómicos, (3), 1-31.

HernándeZ, S. (1972). El desarrollo capitalista del campo chileno. Sociedad y Desarrollo, (3), 25-36.

Huerta, M. A. (1989). Otro agro para Chile: Historia de la reforma agraria en el proceso social y político. Santiago: CESOC.

JaRvis, L. (1985). Chilean Agriculture under Military Rule: From Reform to Reaction, 1973-1980. Berkeley: University of California Press.

Johnson, A. L. H. (1978). Internal Migration in Chile to 1920: Its Relationship to the Labor Market, Agricultural Growth, and Urbanization. Unpublished doctoral dissertation. Davis: University of California. 
KAY, C. (1971). Comparative Development of the European Manorial System and the Latin American Hacienda System: An Approach to a Theory of Agrarian Change for Chile. Unpublished doctoral dissertation. Sussex: University of Sussex.

KAY, C. (1977). Review of A. J. Bauer, (1975) "Chilean Rural Society from the Spanish Conquest to 1930". Fournal of Latin American Studies, 9 (1), 164-65.

KaY, C. (1979). The Hacienda System, Proletarianization and Agrarian Reform:The Roads of the Landlord and of the Subordinate Peasant to Capitalism. In M. ALBUQUERQUE \& M. DíAz (Eds.), El sector agrario en América Latina: Estructura económica y cambio social (pp. 23-38). Stockholm: Instituto de Estudios Latinoamericanos.

KAY, C. (1980). El sistema señorial europeo y la hacienda latinoamericana. México, DF: Era.

KAY, C. (1986). Hacia una teoría del cambio agrario en Chile. Santiago: Grupo de Estudios Agro-regionales.

KaY, C. \& Silva, P. (Eds.) (1992). Development and Social Change in the Chilean Countryside: From the Pre-Land Reform Period to the Democratic Transition. Amsterdam: Centro de Estudios y Documentacion Latinoamericanos.

KLubock, T. M. (2014). La Frontera: Forests and Ecological Conflict in Chile's Frontier Territory. Durham/London: Duke University Press.

Loveman, B. (1973). Property, Politics and Rural Labor: Agrarian Reform in Chile, 19191972. Unpublished doctoral dissertation. Bloomington: Indiana University.

Loveman, B. (1976). Struggle in the Countryside: Politics and Rural Labor in Chile, 19191973. Bloomington: Indiana University Press.

Lloyd, R. (Ed.) (1915). Twentieth Century Impressions of Chile; Its History, People, Commerce, Industries, and Resources. London.

MALlon, F. E. (2004). La sangre del copihue: La comunidad mapuche de Nicolás Ailío y el Estado chileno, 1906-2001. Santiago: LOM.

MCBride, G. (1938). Chile: Land and Society. New York: The Lord Baltimore Press.

Moreno, R. (2013). Sin reforma agraria no habría sido posible: Memorias de la reforma agraria chilena, 1958-1970. Santiago: Copygraph.

OsZLAK, O. (2016). La trama oculta del poder: Reforma agraria y comportamiento politico de los terratenientes chilenos, 1958-1973. Santiago: LOM.

OTERo, L. (2006). La huella del fuego: Historia de los bosques nativos: Poblamiento y cambios en el paisaje del sur de Chile. Santiago: Pehuén.

REDONDO, J. (2017). Tierra, trabajo y libertad: Conflictos campesinos e indígenas en la provincia de Cautín (1967-1973). Santiago: LOM.

RENDÓN, B. (2015). Endulzando el ciclo salitrero: Orígenes de la industria de conservas de frutas en Chile, 1880-1930. Unpublished thesis. Santiago: Universidad de Chile.

RoBLES, C. (2002). Agrarian Capitalism in an Export Economy: Chilean Agriculture in the Nitrate Era, 1880-1930. Unpublished doctoral dissertation. Davis: University of California. 
RoBles, C. (2007). Hacendados progresistas y modernización agraria en Chile Central, 1850-1880. Osorno: Universidad de Los Lagos.

Robles, C. (2009a). Agrarian Capitalism and Rural Labour: The Hacienda System in Central Chile, 1870-1920. Fournal of Latin American Studies, (41) 3, 493-526.

RobLEs, C. (2009b). La producción agropecuaria chilena en la "Era del Salitre" (18801930). América Latina en la Historia Económica. Revista de Investigación, (32), 11336.

Robles, C. (2009c). Controlando la mano invisible: La Sociedad Nacional de Agricultura y el mercado de maquinaria agrícola (1889-1922). Historia, 42 (1), 203-33.

Robles, C. (2010a). A Peripheral Mediterranean: The Early "Fruit Industry" in Chile (1910-1940). Historia Agraria, (50), 91-120.

RoBLEs, C. (2010b). Ideología agraria y política económica en una economía exportadora: Chile, 1860-1880. Iberoamericana, (38), 7-28.

RoBles, C. (2011). Movilización rural y reforma agraria en Chile: Huelgas y tomas en la provincia de Valdivia en el "verano caliente' del 71". Paper presented at II Jornadas Interdisciplinarias de Investigación. Mendoza: Universidad Nacional de Cuyo.

RoBles, C. (2012). Fulio Menadier: La agricultura y el progreso de Chile. Santiago: DIBAM.

Robles, C. (2015). Review of T. Klubock, (2014). La Frontera. Forests and Ecological Conflict in Chile's Frontier Territory. Fournal of Agrarian Change, 15 (2), 292-96.

RoBles, C. (2016). Julio Menadier: A Listian Economist in the Chilean Public Sphere, 1850-1880. In A. Mendes \& C. SuPRINYAK (Eds.), The Political Economy of Latin American Independence (pp. 125-40). London: Routledge.

Robles, C. (2017). Sociedad rural y política nacional en Chile Central, 1850-1973. In

I. JAKSIC \& J. L. OsSA (Eds.), Historia política de Chile, 1810-2010 (pp. 423-51). Santiago: Fondo de Cultura Económica.

Robles, C. (2018a). Revolution from below in Panguipulli: Agrarian Reform and Political Conflict under the Popular Unity in Chile. Fournal of Agrarian Change, (18) 3, 606-31.

Robles, C. (2018b). Mechanisation in the Periphery: The Experience of Chilean Agriculture, c. 1850-90. Rural History, (29) 2, 195-216.

Robles, C. (2020a). Frontier Capitalism: Agrarian Expansion in Southern Chile, c. 18901930. Bulletin of Latin American Studies, (forthcoming).

RoBLES, C. (2020b). Modernization in the Periphery:The Introduction of the Tractor in Chile, c. 1910-1935. Agricultural History, (94) 2 (forthcoming).

Robles, C. \& KAY, C. (2018). La transición del sistema de hacienda al capitalismo agrario en Chile Central. In A. Estefane, I. Jaksic \& C. Robles (Eds.), Historia política de Chile, 1810-2010. III: Problemas económicos (pp. 107-39). Santiago: Fondo de Cultura Económica. 
Rojas, A. (2016). Mecanización agrícola y fomento estatal en Chile (1942-1973). América Latina en la Historia Económica. Revista de Investigación, 23 (3), 147-73.

Rojas, A. \& MAnRíquez, P. (Eds.) (2017). Reforma Agraria, 50 años después: Origen y desarrollo del proceso. Talca: Universidad de Talca.

Ruiz-Esquide, A. (2000). Migration, Colonization and Land Policy in the Former Mapuche Frontier: Malleco, 1850-1900. Unpublished doctoral dissertation. New York: Columbia University.

SAlazAR, G. (1984). Entrepreneurs and Peons in the Transition to Industrial Capitalism: Chile, 1820-78. Unpublished doctoral dissertation. Hull: University of Hull.

SALAZAR, G. (1985). Labradores, peones y proletarios. Santiago: Ediciones Sur.

SALÉM, J. (2020). História agrária da revolução chilena: A pedagogia camponesa como campo de batalha. Unpublished doctoral dissertation. São Paulo: Universidad de São Paulo.

SANTANA, R. (1977). Un cas de proletarianisation rurale: L'inquilino. Cahiers du monde hispanique et luso-bresilien, (28), 73-90.

SANTANA, R. (1980). Paysans dominés: Lutte sociale dans les campagnes chiliennes. 19201970. Paris: Centre National de la Recherche Scientifique.

Santana, R. (2006). Agricultura chilena en el siglo XX: Contextos, actores y espacios agricolas. Santiago: Centro de Estudios Regionales Universidad de Los Lagos/Centro de Investigaciones Diego Barros Arana.

Stickell, A. L. JR. (1979). Migration and Mining Labor in Northern Chile in the Nitrate Era, 1880-1930. Unpublished doctoral dissertation. Ann Arbor: Michigan University.

Tinsman, H. (2002). Partners in Conflict:The Politics of Gender, Sexuality, and Labor in the Chilean Agrarian Reform, 1950-1973. Durham: Duke University Press.

Tinsman, H. (2014). Buying into the Regime: Grapes and Consumption in ColdWar Chile and the United States. Durham: Duke University Press.

VALDÉs, X. (1988). La posición de la mujer en la hacienda. Santiago: Centro de Estudios para el Desarrollo de la Mujer.

VALDÉs, X. (1992). Mujer, trabajo y medio ambiente: Los nudos de la modernización agraria. Santiago: Centro de Estudios para el Desarrollo de la Mujer.

VAZELESK, V. (2017). Terra e Liberdade: Comparando Experiências de Reforma e Contrarreforma Agrária no Peru e no Chile (1962-1997). Passagens, 9 (2), 266-85.

Wright, T. C. (1982). Landowners and Reform in Chile:The Sociedad Nacional de Agricultura, 1919-40. Chicago: University of Illinois Press. 